\title{
Studies on the bacteriological qualities of the Buffalo River and three source water dams along its course in the Eastern Cape Province of South Africa
}

\author{
Vincent N. Chigor • Timothy Sibanda • \\ Anthony I. Okoh \\ Received: 18 June 2012 / Accepted: 19 November 2012 /Published online: 13 December 2012 \\ (C) The Author(s) 2012. This article is published with open access at Springerlink.com
}

\begin{abstract}
The Buffalo River and its dams are major surface water sources used for fresh produce irrigation, raw water abstraction and recreation in parts of the Eastern Cape Province in South Africa. Over a 12-month period (August 2010 to July 2011), we assessed the bacteriological qualities of water from the river and 3 source water dams along its course. Faecal indicator bacteria (FIB), including total coliform (TC), faecal coliform (FC) and enterococci (ENT) counts, were high and ranged as follows: $1.9 \times 10^{2}-3.8 \times$ $10^{7}, 0-3.0 \times 10^{5}$ and $0-5.3 \times 10^{5} \mathrm{cfu} / 100 \mathrm{ml}$ for TC, FC and ENT, respectively. Significantly $(P<0.05)$ higher concentrations of FC and ENT were observed at the sampling sites located at the lower reaches of the river compared to the upper reaches, and at Bridle Drift Dam compared to the other two dams. FIB counts mostly exceeded the recommended maximum values suggested by national and international guidelines for safe fresh produce irrigation, domestic applications, full-contact recreation and livestock watering. These results show that the bacteriological qualities of the Buffalo River and dams were poor, and suggest that sewage was dumped into the Buffalo River during the study period. Urban runoffs and effluents of wastewater treatment plants appear to be important sources of faecal
\end{abstract}

Responsible editor: Robert Duran

Electronic supplementary material The online version of this article (doi:10.1007/s11356-012-1348-4) contains supplementary material, which is available to authorized users.

V. N. Chigor · T. Sibanda • A. I. Okoh $(\bowtie)$

Applied and Environmental Microbiology Research Group (AEMREG), Department of Biochemistry and Microbiology, University of Fort Hare, Private Bag X1314, 5700, Alice, South Africa

e-mail: aokoh@ufh.ac.za contamination in the river. We conclude that these water bodies represent significant public health hazards. Provision of adequate sanitary infrastructure will help prevent source water contamination, and public health education aimed at improving personal, household and community hygiene is imperative.

Keywords Surface waters $\cdot$ Water quality $\cdot$ Fresh produce irrigation · Total coliforms · Faecal coliforms · Enterococci · Public health hazards

\section{Introduction}

Surface waters, including dams, rivers and streams, constitute an important source of water for drinking, domestic, agricultural, recreational and other purposes. However, they are vulnerable to pollution and are frequently contaminated with faecal matter (Effler et al. 2001; Kistemann et al. 2002). Nonpoint sources of such contamination include domestic and wild animal defecation, malfunctioning sewage and septic systems, storm water drainage and urban runoff (Kistemann et al. 2002; Chigor et al. 2012). Point sources include municipal wastewater treatment plants (Shuval 1990; Okoh et al. 2007; Igbinosa and Okoh 2009; Lata et al. 2009: Chigor et al. 2010a; Odjadjare et al. 2010), and drainage from areas where livestock are handled (Williams et al. 2012).

Coliforms and enterococci are indicator organisms used worldwide to monitor water quality (Toranzos and McFeters 1997; APHA 1998; Anderson et al. 2005; Harwood et al. 2005; Gersberg et al. 2006). The detection of these indicators in water signifies faecal pollution, which could have detrimental effects on public health, the economy, and on ecological balance and functioning (Gourmelon et al. 2007; 
Abdelzaher et al. 2010; MacIntyre and de Villiers 2010). The public health risks associated with faecal pollution include the introduction of microbial pathogens (APHA 1998; Pruss et al. 2002; Okoh et al. 2007; WHO 2008) and antibiotic-resistant strains of bacterial pathogens, which could result in the transfer of resistance to previously susceptible strains or species in aquatic environments (Ash et al. 2002; Zhang et al. 2009; Chigor et al. 2010b).

Contamination of surface water bodies with pathogenic agents (including bacteria, viruses and protozoa) could result in the transmission of waterborne and water-related diseases to people using the water for domestic purposes (Fong and Lipp 2005; World Health Organization 2008), to swimmers (Gersberg et al. 2006; Abdelzaher et al. 2010), and to agricultural workers and the consumers of crops irrigated with polluted waters (Shuval 1990; Mohanty et al. 2002; Gemmell and Schmidt 2012). Many viral, bacterial and parasitic diseases have been associated with waterborne transmission (Hunter 2003). Such infections contribute significantly to the global disease burden (Payment and Riley 2002; Pruss et al. 2002). Among the bacterial pathogens, toxigenic Vibrio cholerae, the aetiological agent of cholera, has caused several pandemics and still represents a serious problem, causing repeated epidemics especially in developing countries (Stewart-Tull 2001; Zahid et al. 2008). Salmonella and Shigella species pose serious public health problems to the developing world (Mills-Robertson et al. 2003; Deering et al. 2012), and the threat from Escherichia coli pathotypes is a rising global challenge (Chigor et al. 2010b; Bielaszewska et al. 2011). Human enteric viruses are the major cause of water-related disease and have been estimated to cause about $30-90 \%$ of gastroenteritis cases worldwide (Fong and Lipp 2005; Bosch et al. 2008) and protozoans such as Cryptosporidium and Giardia have been implicated in outbreaks involving recreational water use and contaminated municipal water (Wilczynski et al. 2012).

In South Africa, although water infrastructures are well developed in urban areas, in rural communities, they are either poorly developed or nonexistent (Obi et al. 2004). Available data (2008) reveals that more than $40 \%$ of the South African populations dwell in rural areas (DWAF 2010). In many rural areas, over $75 \%$ of poor households have no access to treated tap water (DWAF 2004). Consequently, many households (approximately $74 \%$ of all rural households) rely solely on untreated stream or river water (DWAF 2004; Obi et al. 2004; RHP 2004). Only $13.6 \%$ of the Eastern Cape population of about 7.3 million has access to pipe-borne water either in their dwelling place or within $200 \mathrm{~m}$ (MDB 2010). Numerous studies have, however, shown that such water sources are susceptible to pollution, are contaminated and constitute serious public health risks in South Africa (Jagals 1997; Morrison et al. 2001;
Muller et al. 2001; Obi et al. 2002; Diergaardt et al. 2004; Igbinosa and Okoh 2009; Odjadjare and Okoh 2010).

Buffalo River, located in the Eastern Cape Province, is important as the major water source for urban, rural, industrial and irrigation consumers, as well as for recreational purposes in one of the most populous areas on the East coast of southern Africa. Despite its importance, there appears to be no report on the microbial quality of this river. The 2004 River Health Programme (RHP) report on the Buffalo River was based on such indices as diversity of habitats, geomorphology and riparian vegetation that served as indicators of ecological health (RHP 2004). Although the report says that blockages in the sewerage systems, inadequate treatment capacity and poor management result in the discharge of partially treated and untreated sewage into the river and dams, no bacteriological data was presented. The paucity of reports on the bacteriological quality of Buffalo River and the source water dams located along its course calls for attention. It was therefore important to carry out this study with the primary goal of determining the bacteriological quality of these essential surface waters to assess the public health risks attendant to their uses.

\section{Materials and methods}

Study area and samples collection

The Buffalo River (Fig. 1) is located in the Eastern Cape Province of South Africa. Rising at an altitude of 1,200 m in the Amathola Mountains of the Eastern Cape, it flows southeastwards for about $126 \mathrm{~km}$ before emptying into the Indian Ocean at East London harbour. The climate is warm and temperate, and temperatures are moderate in the coastal zone ( 8 to $39^{\circ} \mathrm{C}$ ) with a warm mean annual value of $21^{\circ} \mathrm{C}$ while inland temperatures vary between -2 and $42^{\circ} \mathrm{C}$ with a mean annual value of $18{ }^{\circ} \mathrm{C}$ (RHP 2004). The mainly summer rainfall in the Buffalo River catchment ranges from 400 to more than $1,000 \mathrm{~mm}$ per year with an annual mean value of about $700 \mathrm{~mm}$ (RHP 2004). Precipitation measurements were beyond the scope of the present study. Measurements of the river dimensions and flow were also beyond the scope of this study. Recorded average width of the highly meandering river ranged from about $4 \mathrm{~m}$ in the upper reaches to between 40 and $50 \mathrm{~m}$ at the lower reaches (RHP 2004). South Africa's only river port, the Port of East London, is located at the mouth of the Buffalo River. Along the river there are four dams that serve as raw water sources for drinking water production by water treatment works (WTW), including King William's Town WTW, Schornville WTW and East London WTW, supplying water to the urban areas of King William's Town, Zwelitsha, Mdantsane and East London and the surrounding 


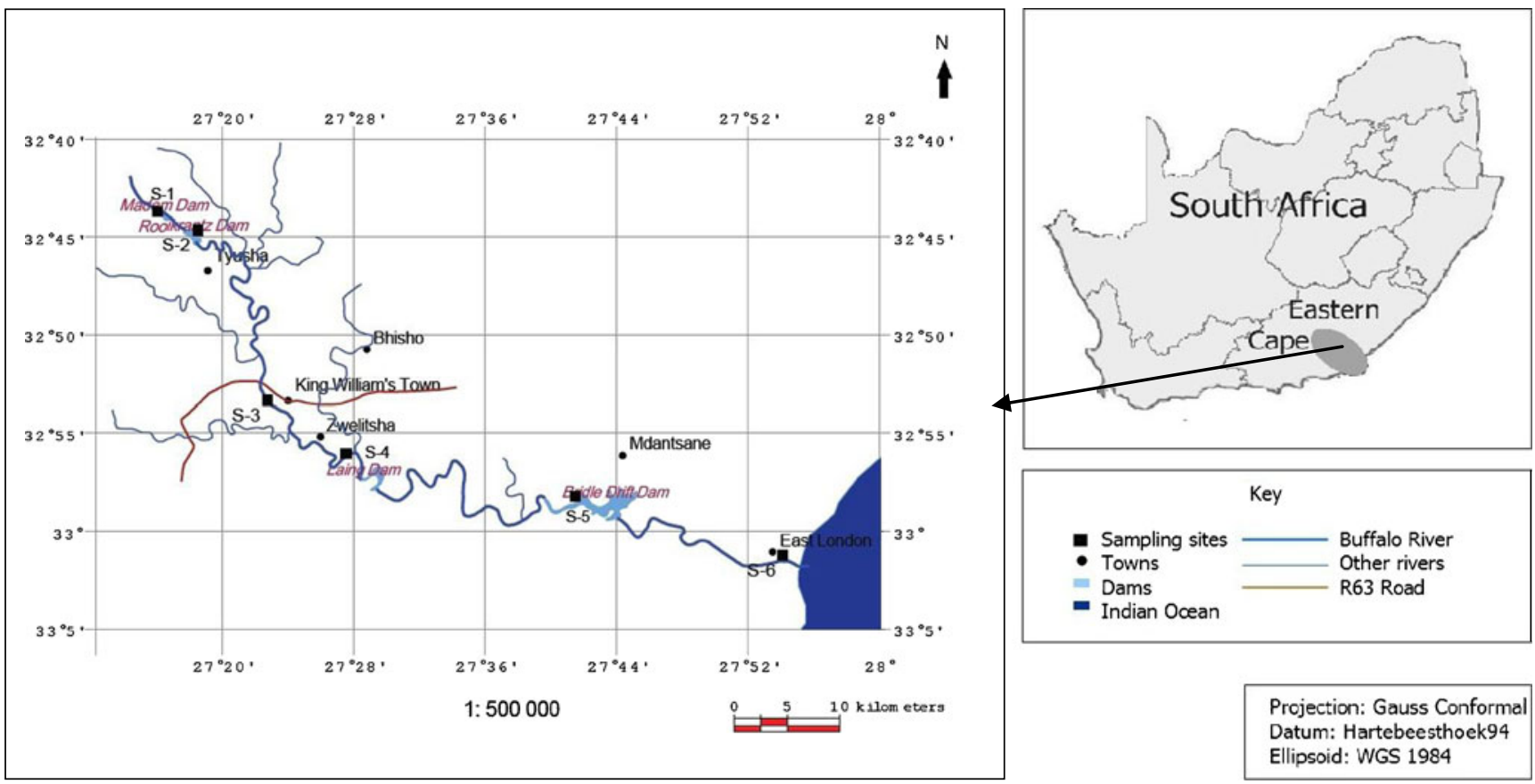

Fig. 1 The study area and sampling sites, S1-S6 Maden Dam, Rooikrantz Dam, King William's Town, Eluxolzweni, Bridle Drift Dam and Parkside. With kind permission from Springer Science+Business Media: Food and Environmental Virology, Quantitative Detection and
Characterization of Human Adenoviruses in the Buffalo River in the Eastern Cape Province of South Africa, 4, 2012, 200, VN Chigor and AI Okoh, Fig. 1

spatially discrete points at each sampling site, at a depth of approximately $15 \mathrm{~cm}$ below the water surface, using sterile 1.75-1 screw-capped bottles. Ample air space was left in the bottles to facilitate mixing by shaking before examination. The samples were immediately placed in a lightproof insulated box containing ice-packs and transported to the Applied and Environmental Microbiology Research Group (AEMREG) Laboratory at the University of Fort Hare, Alice, South Africa, through a journey of about $2 \mathrm{~h}$. Upon arrival, the samples were immediately stored at $4{ }^{\circ} \mathrm{C}$ until processing. All the samples were processed within $8 \mathrm{~h}$ of collection as recommended by American Public Health Association (APHA 1998).

Enumeration of water quality indicators

Equal volumes $(500 \mathrm{ml})$ of the duplicate samples were mixed and the homogenate analysed. The total coliforms (TC), faecal coliforms (FC) and enterococci (ENT) counts were determined by membrane filtration according to standard methods (APHA 1998). For TC, samples were processed by making tenfold serial dilutions with $100 \mathrm{ml}$ of each composite and filtering $100 \mathrm{ml}$ of water through membrane filters (47-mm diameter, $0.45 \mu \mathrm{m}$ pore size; Millipore, County Cork, Ireland). Thereafter, the Millipore filter papers were placed on m-Endo agar (Merck, Wadeville, South Africa) and incubated at $37{ }^{\circ} \mathrm{C}$ for $24 \mathrm{~h}$. Typical red colonies
From August 2010 to July 2011, between 8 a.m. and 1 p.m., duplicate water samples were collected once monthly, from 
Table 1 Wastewater treatment plants in the Buffalo River catchment

\begin{tabular}{|c|c|c|c|c|c|c|}
\hline $\begin{array}{l}\text { Wastewater } \\
\text { treatment } \\
\text { plant }\end{array}$ & Technology & $\begin{array}{l}\text { Design } \\
\text { capacity } \\
\left(\mathrm{M} 1 / \mathrm{d}^{\mathrm{a}}\right)\end{array}$ & $\begin{array}{l}\text { Operational } \\
\text { capacity } \\
(\%)\end{array}$ & $\begin{array}{l}\text { Microbiological } \\
\text { compliance }(\%)\end{array}$ & Highest risk area & $\begin{array}{l}\text { Point of discharge entry into } \\
\text { the Buffalo River }\end{array}$ \\
\hline Schornville & $\begin{array}{l}\text { Activated sludge, biofilters, } \\
\text { anaerobic digestion and } \\
\text { sludge drying beds }\end{array}$ & 4.8 & 133.3 & 0.0 & $\begin{array}{l}\text { Poor effluent compliance, } \\
\text { operating capacity } \\
\text { exceeds design capacity }\end{array}$ & $\begin{array}{l}\text { King William's Town; } \\
\text { upstream of S-3 }\end{array}$ \\
\hline Zwelitsha & $\begin{array}{l}\text { Biofilters, anaerobic digestion } \\
\text { and sludge drying beds }\end{array}$ & 9.3 & 84.9 & 16 & Poor effluent compliance & $\begin{array}{l}\text { Between Zwelitsha and } \\
\text { Phakamisa; upstream of S-4 }\end{array}$ \\
\hline Breidbach & Oxidation ponds & 0.8 & 162.5 & 35 & $\begin{array}{l}\text { Poor effluent compliance, } \\
\text { operating capacity } \\
\text { exceeds design capacity }\end{array}$ & $\begin{array}{l}\text { Via Yellowwoods River; } \\
\text { downstream of S-4 }\end{array}$ \\
\hline Bisho & Oxidation ponds & 0.8 & 237.5 & 32 & $\begin{array}{l}\text { Poor effluent compliance, } \\
\text { operating capacity } \\
\text { exceeds design capacity }\end{array}$ & $\begin{array}{l}\text { Via Yellowwoods River; } \\
\text { downstream of S-4 }\end{array}$ \\
\hline Postdam & $\begin{array}{l}\text { Biofilters, anaerobic digestion } \\
\text { and sludge drying beds }\end{array}$ & 9.2 & 51.1 & 2.0 & Poor effluent compliance & $\begin{array}{l}\text { Postdam Village; upstream } \\
\text { of S-5 }\end{array}$ \\
\hline $\begin{array}{l}\text { Mdantsane } \\
\text { East }\end{array}$ & $\begin{array}{l}\text { Biofilters, anaerobic digestion } \\
\text { and sludge drying beds }\end{array}$ & 24 & 43.8 & 0.0 & Poor effluent compliance & $\begin{array}{l}\text { Mdantsane; downstream of } \\
\text { S-5 }\end{array}$ \\
\hline Reeston & $\begin{array}{l}\text { Activated sludge and sludge } \\
\text { lagoons }\end{array}$ & 2.5 & 44 & 68.0 & Poor effluent compliance & $\begin{array}{l}\text { Reeston; upstream of Umtiza } \\
\text { Nature Reserve }\end{array}$ \\
\hline $\begin{array}{l}\text { Amalinda } \\
\text { Central }\end{array}$ & $\begin{array}{l}\text { Petro system, Biofilters, } \\
\text { anaerobic digestion and } \\
\text { sludge drying beds }\end{array}$ & 5 & 154 & 46 & $\begin{array}{l}\text { Effluent compliance, } \\
\text { operating capacity } \\
\text { exceeds design capacity }\end{array}$ & Parkside; upstream of S-6 \\
\hline West Bank & $\begin{array}{l}\text { Rotating drum screens and } \\
\text { marine outfall }\end{array}$ & 40 & 33.5 & 100 & & $\begin{array}{l}\text { East London harbour; } \\
\text { downstream of S-6 }\end{array}$ \\
\hline
\end{tabular}

Source: Except for the 7th column, the data shown in this table was extracted from the 2012 Green Drop Progress Report (DWAF 2012)

${ }^{\text {a }} \mathrm{Ml} / \mathrm{d}$ Mega litre per day

${ }^{\mathrm{b}}$ The percentage compliance was calculated for E. coli or faecal coliform over the period 1 July 2010-30 June 2011

with a metallic sheen were enumerated and reported as colony forming units (cfu)/100 ml surface water. For FC, composite samples were processed by making serial dilutions as described above and filtering $100 \mathrm{ml}$ of water through membrane filters (47-mm diameter, $0.45 \mu \mathrm{m}$ pore size). The Millipore filter papers were then placed on $\mathrm{m}-\mathrm{FC}$ agar (Merck, Wadeville, South Africa) and incubated at $44.5{ }^{\circ} \mathrm{C}$ for $24 \mathrm{~h}$. Colonies exhibiting any shades of blue were counted and reported as cfu/100 $\mathrm{ml}$ surface water. E. coli (ATCC 29522) was used as a positive control in both the TC and FC tests. For the enumeration of ENT, water samples were diluted and filtered as described above and the Millipore filter paper was placed on Enterococcus Selective Agar (Merck, Wadeville, South Africa). After incubation at $37^{\circ} \mathrm{C}$ for $48 \mathrm{~h}$, all brown to black colonies with a typical dark halo were counted as faecal enterococci and reported as cfu/100 ml surface water. Enterococcus faecalis (ATCC 29212) was used as a positive control. Analysis per sample per parameter was done in triplicate.

\section{Statistical analysis}

Using SPSS (IBM SPSS Statistics 19), one-way analysis of variance and Tukey's multiple range tests were used to compare the mean values of the tested parameters for all the different sampling sites, months and seasons. Statistical significance was set at $P$ values $<0.05$.

\section{Results and discussion}

Faecal indicator bacteria (FIB) concentrations observed in this study were high across all sites. Total coliforms (TC), faecal coliforms (FC) and enterococci concentrations varied widely and ranged from $1.9 \times 10^{2}-3.8 \times 10^{7} \mathrm{cfu} / 100 \mathrm{ml}$, $0-3.0 \times 10^{5} \mathrm{cfu} / 100 \mathrm{ml}$ and $0-5.3 \times 10^{5} \mathrm{cfu} / 100 \mathrm{ml}$, respectively. These concentrations and wide variations are similar to findings elsewhere (Schets et al. 2008; Lata et al. 2009; USEPA 2010; Chigor et al. 2012).

The average concentrations of the FIB were compared per sampling site across the four South Africa seasons including spring (September, October and November), summer (December, January and February), autumn (March, April and May) and winter (June, July and August). No seasonal trend was observed. This is not surprising considering that rainfall and storm events occurred across the seasons during the study period and previous reports have shown that extreme rainfall and runoff result in significant 
increases in microbial loads of surface waters (Kistemann et al. 2002; Chigor et al. 2012). The continuous faecal contamination of the river appears to emanate also from the WTPs in the catchment (Table 1). There is a prevalence of overloading and recorded microbiological non-compliance amongst the WTPs (RHP 2004; DWAF 2012). Five of the 9 WTPs are currently overloaded with operational capacities ranging from 133.3 to $237 \%$. Of the 9 WTPs, whose effluents are discharged directly into Buffalo River, only one (West Bank) currently records a satisfactory microbiological compliance (MC). The compliance level of the other nine ranged from 0 to $68 \%$, with $77.8 \%$ of the plants recording $\mathrm{MC}$ values below $50 \%$. While the $\mathrm{MC}$ level at the Postdam WTP was as low as $2 \%$, the Schornville and Mdantsane East plants showed zero compliance (DWAF 2012). Consequently, untreated or inadequately treated sewage is discharged of into the river and dams.

The contribution of individual point sources to the microbial load of surface water is variable. Inefficient WTPs will discharge final effluents with unacceptable microbial counts into the receiving water bodies (Casadio et al. 2010; Odjadjare et al. 2010). Even in cases where the WTPs are efficient and there is significant reduction of enteric microbes, heavy rainfall events may still result in flooding of these plants and the washing off of raw sewage into surface waters. Reports have continued to associate faecal pollution and waterborne disease with heavy rainfall (Hunter 2003; Drayna et al. 2010). The study period was preceded by drought (Clarke et al. 2012) in which the study area experienced very low rainfall, and during reconnaissance visits and selection of sampling sites in MayJune, 2010, water levels at the dams were observed to be very low. The heavy rainfall that returned before the onset of sampling in August 2010 did continue, with varying intensity, throughout the study period. The results presented in this study agree with other reports that storm events can lead to high counts of indicator bacteria in river waters (Kistemann et al. 2002; Hunter 2003; Chigor et al. 2012) and suggest that people swimming in Buffalo River are at an increased risk of illness.

Figure 2 shows the spatial variation in the counts of the FIB in the Buffalo River and compares the 12-month mean values for the three indicators assessed in this study. The significantly higher $(P<0.05)$ mean concentrations of the indicator bacteria recorded at Bridle Drift Dam $\left(\mathrm{TC}, 3.4 \times 10^{4} \mathrm{cfu} / 100 \mathrm{ml}\right.$ FC, $1.9 \times 10^{3} \mathrm{cfu} / 100 \mathrm{ml}$; ENT, $\left.2.9 \times 10^{2} \mathrm{cfu} / 100 \mathrm{ml}\right)$ compared to the two other dams, Maden $\left(\mathrm{TC}, 3.9 \times 10^{3} \mathrm{cfu} / 100 \mathrm{ml}\right.$ FC, $3.8 \times 10^{2} \mathrm{cfu} / 100 \mathrm{ml}$; ENT, $\left.1.5 \times 10^{2} \mathrm{cfu} / 100 \mathrm{ml}\right)$ and Rooikrantz Dam (TC, $6.0 \times 10^{3} \mathrm{cfu} / 100 \mathrm{ml}$; FC, $2.0 \times 10^{2} \mathrm{cfu} /$ $100 \mathrm{ml}$; ENT, $7.1 \times 10^{1} \mathrm{cfu} / 100 \mathrm{ml}$ ) indicate that this is the most contaminated dam.

A uniform trend was observed for the three bacteriological parameters tested. Significantly higher $(P<0.05)$ mean concentrations of FIB were recorded at the sampling sites located at the lower reaches (King William's Town, Eluxolzweni, Bridle Drift Dam and Parkside) of the river compared to those at the upper reaches (Maden Dam and Rooikrantz Dam). For TC, mean concentrations observed at Maden Dam and Roikrantz were $3.9 \times 10^{3} \mathrm{cfu} / 100 \mathrm{ml}$ and $6.0 \times 10^{3} \mathrm{cfu} / 100 \mathrm{ml}$, respectively, while at the lower reaches mean concentrations ranged from $3.4 \times 10^{4} \mathrm{cfu} / 100 \mathrm{ml}$ recorded at Bridle Drift Dam to $3.2 \times 10^{6} \mathrm{cfu} / 100 \mathrm{ml} \mathrm{ob}-$ served at Parkside. Both the FC and enterococci showed trends similar to that of TC with the lower-reaches sites yielding significantly $(P<0.05)$ higher mean concentrations ranging from $1.9 \times 10^{3}-2.7 \times 10^{4} \mathrm{cfu} / 100 \mathrm{ml}$ for $\mathrm{FC}$, and from $2.9 \times 10^{2}-4.8 \times 10^{4} \mathrm{cfu} / 100 \mathrm{ml}$ for enterococci. This could be attributable to anthropogenic activities and increased populations in the different catchments.

A recent report (Williams et al. 2012) highlighted the need for land-use types associated with particular areas of a watercourse to be considered as a central factor in models that aim to predict pathogen risk in environmental waters. In this study, the least counts of FIB were detected at Maden and Rooikrantz dams. Although there are a few sparsely populated settlements, much of the catchment upstream of this area is a protected state forest, so pressures from human activity are limited to forest management and recreational activities. The significantly higher counts recorded at the lower reaches including at King William's Town, Eluxolzweni and Bridle Drift Dam could be attributed to catchment conditions and land-use patterns, which our data suggests to have remained
Fig. 2 Spatial variation in mean concentrations of faecal indicator bacteria at the six sites (S1-S6) located on the Buffalo River. Composite samples were collected monthly at the each site for a total of 12 months (August 2010 to July 2011) and each sample was analysed in triplicate. Reported values are the average counts for the entire 12-month period

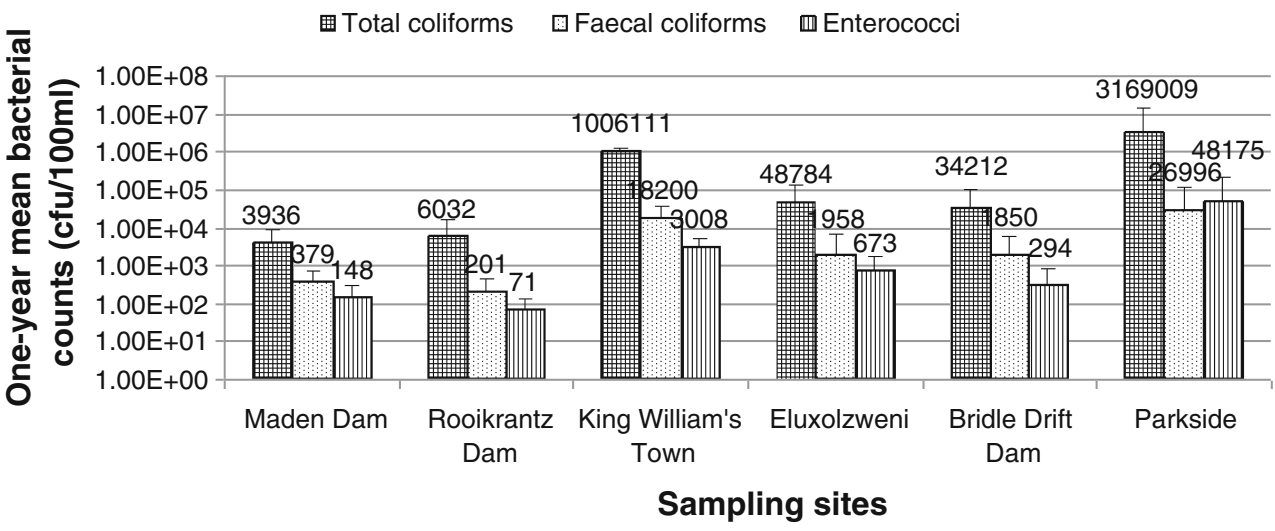


unchanged nearly a decade since the RHP studies (RHP 2004). This area is heavily impacted by dense rural and urban populations, and WTPs (Table 1) which are reported to be overloaded and spilling effluents that are either untreated or insufficiently treated into the river (DWAF 2012). Irrigation agriculture along the river catchment, even on steep slopes, is extensive and in situ herd watering is common. Downstream of Bridle Drift Dam, the Buffalo River passes through the Umtiza Nature Reserve where anthropogenic impacts are low and the river's self-purification process is therefore enhanced. The impact of this, in addition to high salinity of the estuary would have been very low bacterial counts at Parkside. Conversely, higher counts (Fig. 2) were recorded, and this could be attributed to the impact of the Amalinda Central WTP effluents and stormwater runoff from the East London city centre (RHP 2004).

Expectedly, the general trend at all the sites was that TC concentrations were significantly $(P<0.05)$ higher than FC concentrations. It is also evident from Fig. 2 that across the sites, FC concentrations recorded in this study were always higher than the ENT concentrations, except at Parkside where the mean ENT concentration was higher than that of FC. Previous studies have reported that FC shows greater persistence in freshwater than ENT (Sinton et al. 2002; Anderson et al. 2005). In their report on the persistence and differential survival of faecal indicator bacteria in subtropical waters and sediments, Anderson et al. (2005), who measured persistence by decay rates (change in culturable concentrations over time), showed that faecal coliform decay rates were significantly lower than those of ENT in freshwater. This higher persistence of FC has been attributed, in part, to the sensitivity of ENT to photooxidation (Bernier et al. 2009) that results in ENT surviving less easily, compared to faecal coliforms, in river water. The higher ENT concentrations observed at
Parkside could be attributable to the fact that ENT have been shown to survive harsh environments that is associated with river estuaries (He and Jiang 2005) and characterized by extremes of salinity as observed at Parkside (range, 32.47-33.62). Longer persistence of ENT than of FC in saline waters has been documented (Davies et al. 1995).

Figures 3 to 5 show the monthly variation in counts of faecal indicator bacteria observed at the six sites on the Buffalo River.

The FC counts were significantly $(P<0.05)$ higher at King William's Town in 8 of the 12 months than at all the other sites. In August 2010 and September 2010, although FC counts at King William's Town and Eluxolzweni were significantly $(P<0.05)$ higher than the counts recorded at the rest of the sites, the difference between the means at both sites was not significant. For ENT, significantly higher counts were recorded at King William's Town than at all the other sites throughout the study period, except in June and July during which counts at Parkside were significantly higher. The significantly higher counts of the indicator bacteria recorded at King William's Town compared to the other sites suggests that this is the most contaminated site.

The general trend suggests that Buffalo River is continuously being polluted with faecal matter from a variety of sources; resulting in for example, severe eutrophication and extensive growth of water hyacinths. The level of algal growth observed at Eluxolzweni stretch of the Buffalo River should not be overlooked. Besides representing the ecological risks attendant to faecal pollution of surface waters, blooms of various planktonic species have been shown to release cyanobacterial toxins into waters thereby presenting an additional water supply hazard (Hitzfeld et al. 2000). The very high counts of indicator bacteria recorded at Parkside (FC, $3.0 \times$ $10^{5} \mathrm{cfu} / 100 \mathrm{ml}$ and enterococci, $5.3 \times 10^{5} \mathrm{cfu} / 100 \mathrm{ml}$ ) in June,

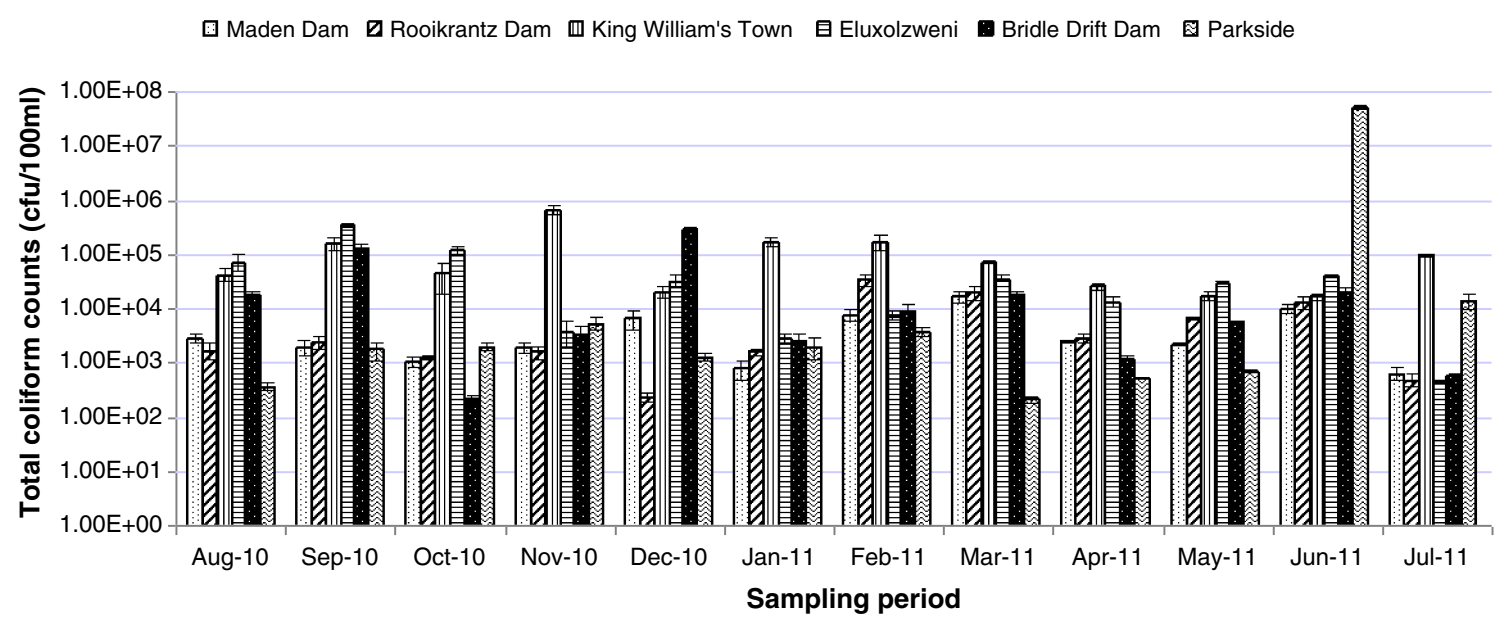

Fig. 3 Monthly variation in concentrations of total coliforms in water samples collected from the six sites (S1-S6) located on the Buffalo River. Each composite sample, collected monthly at each site, was analysed in triplicate. The triplicate values obtained for each sample were averaged to obtain the results reported 


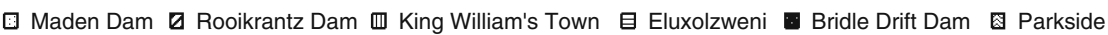

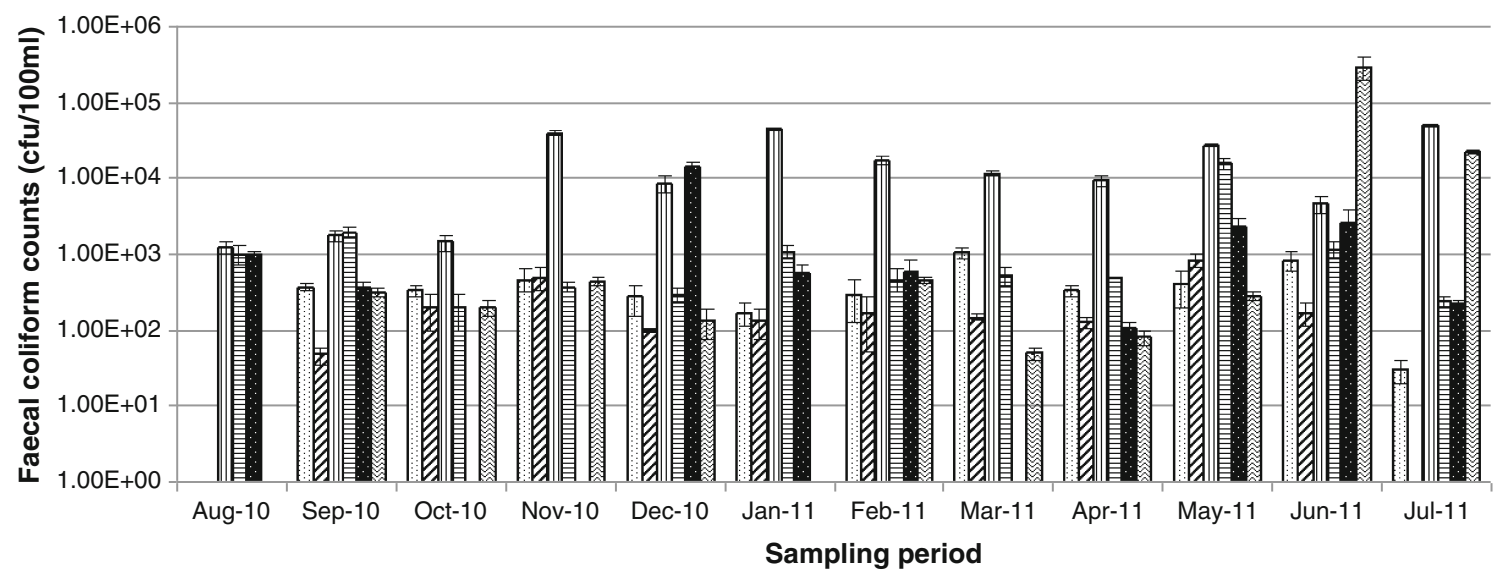

Fig. 4 Monthly variation in concentrations of faecal coliforms in water samples collected from the six sites (S1-S6) located on the Buffalo River. Each composite sample, collected monthly at each site, was analysed in triplicate. The triplicate values obtained for each sample were averaged to obtain the results reported

mid-afternoon (USEPA 2010). The decrease of indicator bacteria during daylight hours results from inactivation of organisms by incident solar radiation among other factors (Sinton et al. 2002). In this study, sampling at Maden Dam and Rooikrantz Dam were always done between 8 a.m. and 9 a.m., while collection of samples at the remaining sites occurred around noon. This could help explain why, despite limited anthropogenic influences at both dams, the FIB counts at both upper catchment dams (Maden and Rooikrantz) were in some cases not significantly different from those at the other three freshwater sampling sites located in the lower reaches of the Buffalo River, as evident in Figs. 3, 4 and 5, and typified by the concentrations recorded in September, October and June for FC, ENT and TC respectively. ing, decreasing density during the day (often by several orders of magnitude), reaching the lowest density in the

目Eluxolzweni Bridle Drift Dam Rarkside

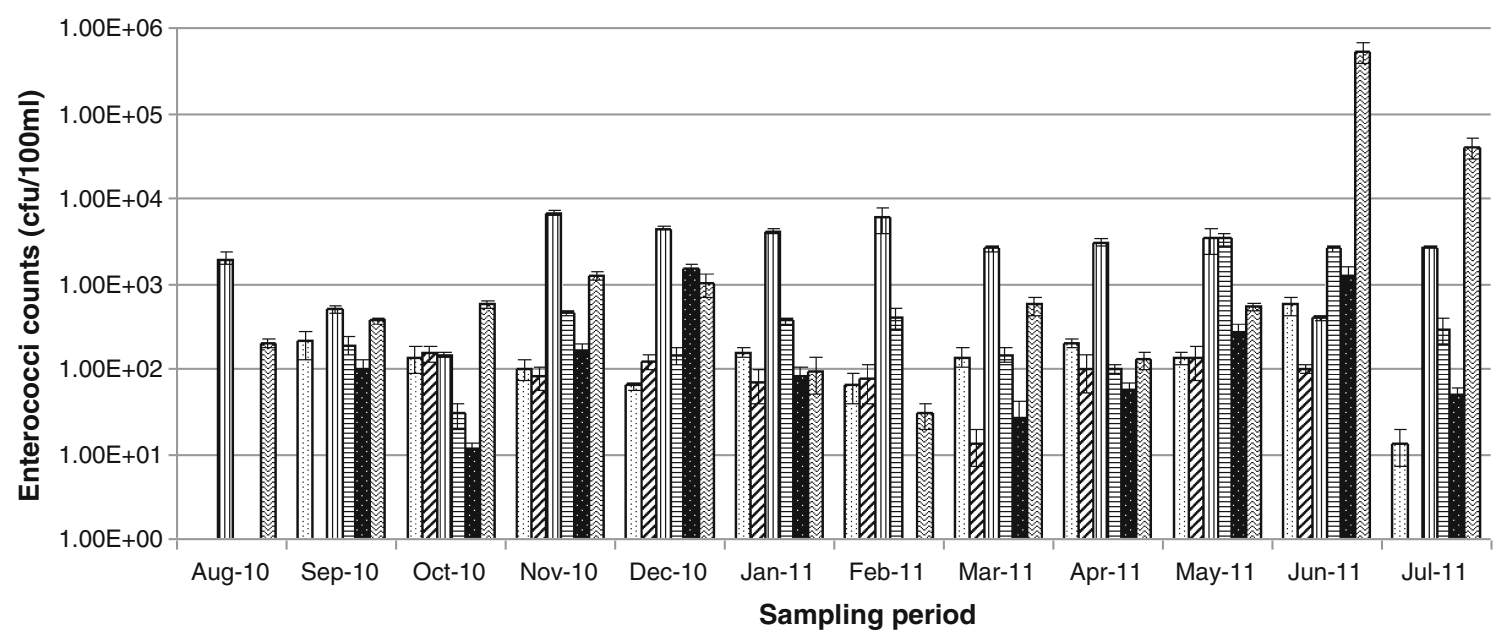

Fig. 5 Monthly variation in concentrations of enterococci in water samples collected from the six sites (S1-S6) located on the Buffalo River. Each composite sample, collected monthly at each site, was analysed in triplicate. The triplicate values obtained for each sample were averaged to obtain the results reported 
Further, despite its location in the lower catchment, Bridle Drift Dam recorded lower FIB counts compared to Maden and Rooikrantz dams at the upper catchment in some of the months (e.g. October for TC and ENT and April for TC and FC). This, however, may not be as a result of reduced faecal pollution, but could be due to dilution in higher water volumes at the Bridle Drift Dam.

Contamination of watercourses with faecal matter represents a significant risk to public health due to the associated risk from human pathogens, and the concentration of indicator microorganisms in a body of water is used to estimate the health risk to users for domestic, irrigational and recreational purposes (Abdelzaher et al. 2010). Table 2 shows the results of the evaluation of the pollution level of the Buffalo River based on bacteriological standards and guidelines. Faecal coliform and even total coliform counts should be zero (per $100 \mathrm{ml}$ ) of sample in domestic water supplies, piped or unpiped, treated or untreated (DWAF 1996a; WHO 2008). While all the samples (100\%) exceeded this acceptable limit for TC count, $89 \%$ of the samples yielded counts that were above the FC standard limit, indicating that the quality of Buffalo River water is very poor. Poor water quality poses a serious health risk for rural communities, since many households rely solely on untreated river water for domestic purposes (RHP 2004). The river water poses greater health risks for infants, some of the elderly, and people with severely compromised immune systems. The potential impact is more profound considering the high number of people, in the Eastern Cape, whose immune systems are compromised by HIV/AIDS (Obi et al. 2006).

By the United States Environmental Protection Agency (USEPA) limits, recreational waters with concentrations exceeding the maximum contaminant limit of 33 or $200 \mathrm{cfu} / 100 \mathrm{ml}$ for ENT or FC respectively presents a health risk (USEPA 1986; Abdelzaher et al. 2010). The South Africa Department of Water Affairs (SA-DWAF) sets target water quality ranges for both parameters of $0-30 \mathrm{cfu} / 100 \mathrm{ml}$ for ENT and 0-130 cfu/100 $\mathrm{ml}$ for FC (DWAF 1996b). The percentage of water samples in this study that exceeded these limits were $71-79 \%$ for FC and $82-85 \%$ for ENT. At Parkside, where recreational activities are most pronounced on the Buffalo River, unacceptable ENT concentrations were observed in $92-100 \%$ of the water samples.

Agriculture is widespread in the middle reaches of Buffalo River catchment (from the foothill zone downstream of

Table 2 Evaluation of the pollution level of the Buffalo River based on bacteriological standards and guidelines

\begin{tabular}{|c|c|c|c|c|c|c|c|c|}
\hline \multirow[t]{2}{*}{ Water use } & \multirow{2}{*}{$\begin{array}{l}\text { Standard limit/target water } \\
\text { quality range }(\mathrm{CFU} / 100 \mathrm{ml})\end{array}$} & \multicolumn{7}{|c|}{ Number of samples (\%) with FIB concentrations that exceeded standard/guideline limits ${ }^{\mathrm{a}}$} \\
\hline & & Maden & $\begin{array}{l}\text { Rooikrantz } \\
\text { Dam }\end{array}$ & $\begin{array}{l}\text { King William's } \\
\text { Town }\end{array}$ & Eluxolzweni & $\begin{array}{l}\text { Bridle Drift } \\
\text { Dam }\end{array}$ & Parkside & Total \\
\hline \multirow[t]{3}{*}{ Domestic/drinking } & WHO/South Africa & & & & & & & \\
\hline & $<1 \mathrm{TC}^{\mathrm{b}}$ & $12(100)$ & $12(100)$ & $12(100)$ & $12(100)$ & $12(100)$ & $12(100)$ & $72(100)$ \\
\hline & $<1 \mathrm{FC}$ & $11(92)$ & $10(83)$ & $12(100)$ & $12(100)$ & $9(75)$ & $10(83)$ & $64(89)$ \\
\hline \multirow[t]{6}{*}{ Full-contact recreation } & USEPA & & & & & & & \\
\hline & $200 \mathrm{FC}$ & $9(75)$ & $3(25)$ & $12(100)$ & $12(100)$ & $8(67)$ & $7(58)$ & $51(71)$ \\
\hline & 33 Enterococci & $10(83)$ & $8(67)$ & $12(100)$ & $10(83)$ & $8(67)$ & $11(92)$ & $59(82)$ \\
\hline & South Africa & & & & & & & \\
\hline & $0-130 \mathrm{FC}$ & $10(83)$ & $7(58)$ & $12(100)$ & $12(100)$ & $8(67)$ & $8(67)$ & $57(79)$ \\
\hline & 0-30 Enterococci & $10(83)$ & $8(67)$ & $12(100)$ & $11(92)$ & $8(67)$ & $12(100)$ & $61(85)$ \\
\hline \multirow{3}{*}{$\begin{array}{l}\text { Abstraction of raw water } \\
\text { for full treatment }\end{array}$} & European Community & & & & & & & \\
\hline & $5,000 \mathrm{TC}$ & $4(33)$ & $4(33)$ & $12(100)$ & $9(75)$ & $7(58)$ & $1(8)$ & $37(51)$ \\
\hline & $2,000 \mathrm{FC}$ & $0(0)$ & $0(0)$ & $9(75)$ & $2(17)$ & $3(25)$ & $2(17)$ & $16(22)$ \\
\hline \multirow{4}{*}{$\begin{array}{l}\text { Unrestricted irrigation } \\
\text { (fresh produce) }\end{array}$} & USEPA/South Africa & & & & & & & \\
\hline & $<1 \mathrm{FC}$ & $11(92)$ & $10(83)$ & $12(100)$ & $12(100)$ & $9(75)$ & $10(83)$ & $64(89)$ \\
\hline & WHO/USEPA & & & & & & & \\
\hline & $\leq 1,000 \mathrm{FC}$ & $1(8)$ & $0(0)$ & $12(100)$ & $5(42)$ & $4(33)$ & $1(8)$ & $23(32)$ \\
\hline \multirow[t]{2}{*}{ Livestock watering } & South Africa & & & & & & & \\
\hline & $0-200 \mathrm{FC}$ & $9(75)$ & $3(25)$ & $12(100)$ & $12(100)$ & $8(67)$ & $7(58)$ & $51(71)$ \\
\hline
\end{tabular}

References: Blumenthal et al. (2000), (DWAF 1996a, b, c, d, f), Tebbut (1992), USEPA (1986, 1992), WHO (2008)

${ }^{\mathrm{a}}$ Number of samples collected per site $=12$; total number samples collected from the Buffalo River and its dams $=72$

${ }^{\mathrm{b}}$ TC total coliforms; FC faecal coliforms; CFU colony forming units; FIB faecal indicator bacteria; WHO World Health Organization; USEPA United States Environmental Protection Agency 
Rooikrantz Dam to King William's Town and as far as Bridle Drift Dam), with local areas of intensive irrigation that provide fresh produce (RHP 2004). Irrigation water used for fruit and vegetable crops can be a potential cause of contamination with microbial pathogens. For unrestricted irrigation (that is, for uses that include crops likely to be eaten uncooked), only $32 \%$ of all the 72 water samples analysed in this study exceeded the WHO guideline for faecal coliform bacteria ( $\leq 1000 \mathrm{FC} / 100 \mathrm{ml}$ ) (Blumenthal et al. 2000). This, however, gives an underestimation of the potential hazards that may arise from the use the Buffalo River water in fresh produce irrigation. The USEPA and SA-DWAF have recommended strict guidelines of no detectable faecal coliform bacteria being allowed in $100 \mathrm{ml}$ of water for fresh produce irrigation (USEPA 1992; DWAF 1996c, e). In this study, FC concentrations exceeding this zero limit were detected in $89 \%$ of the water samples.

The bacterial water quality represents significant threats to the health of not only agricultural workers but also the consumers of fresh produce irrigated with the Buffalo River water, as previous studies have demonstrated the presence and prolonged survival of excreted pathogens on the surface of vegetables irrigated with faecally contaminated water (Beuchat 2002; Gemmell and Schmidt 2012). Considering that cattle farming and in situ herd watering are extensive in the catchment, it is worth noting that the carriage of E. coli $\mathrm{O} 157$ in cattle (LeJeune et al. 2004) and irrigation with water contaminated by animal faeces were the vital factors in the emergence of this pathogen in South Africa (Effler et al. 2001). The risk attendant to irrigation with contaminated water is heightened by the demonstrated ability of this pathogen and Salmonella to migrate to internal locations in plant tissue and thus gain protection from the action of sanitising agents by virtue of inaccessibility (Solomon et al. 2002; Deering et al. 2012).

Of the three dams serving as source raw water for drinking water production, the biggest, Bridle Drift Dam (with a capacity of 101.6 million cubic metres) is the most polluted, with 58 and $25 \%$ of all samples collected this dam yielding TC and FC counts, respectively, that exceeded international limits. The European Union guide limits for surface waters used as raw water for normal full physical and chemical treatment with disinfection suggests maximum concentrations of $<5.0 \times 10^{3} \mathrm{TC} / 100 \mathrm{ml}$ and $<2.0 \times 10^{3} \mathrm{FC} / 100 \mathrm{ml}$, respectively (Tebbut 1992). It is known that most waterborne pathogens have low infective doses (WHO 2008). Knowing also that inadequately treated water may contain pathogens, and that an accidental water treatment failure may pose significant risk to public health, there is an urgent need for provision of adequate sanitary infrastructure that will help prevent source water contamination. People from low socio-economic rural communities in the Buffalo River catchment draw water directly from the river for domestic use which they often drink without any form of treatment like boiling or filtering, as long as it "appears clean". The USEPA source water quality coliform limits for filtration avoidance required that the FC concentration in water prior to disinfection must not exceed 20/ $100 \mathrm{ml}$ in at least $90 \%$ of the samples, or that the TC concentration must not exceed $100 / 100 \mathrm{ml}$ in at least $90 \%$ of the samples (USEPA 2004). The data presented in this study by far exceed these limits that seek to prevent waterborne diseases. The Buffalo River water therefore constitutes a potential health hazard to consumers.

It should be pointed out that specific pathogens were not evaluated in this study. The implication is that there is a probability that a part of the data presented could represent false-negatives (in which FIB were absent in water samples and pathogens were present) or false-positives (FIB were present in the samples and pathogens were absent) results. The risks therefore could have been overestimated or underestimated. In addition, some studies on the relationships between indicator microbes and pathogens have shown that bacteriological indicators might not estimate, reliably, the sanitary risk related to faecal contamination and viral particles in water (Jurzik et al. 2010). However, although in a recent study Abdelzaher et al. (2010) assessed the presence of selected members all three classes of pathogens (viral, protozoan, and bacterial) as well as indicator microbes, the assessment of all possible pathogens is not economically, technologically, or practically feasible. The determination of faecal indicators, such as faecal coliforms or E. coli, as a means for assessing faecal pollution in environmental freshwaters in temperate regions like Europe and North America is widely accepted (Toranzos and McFeters 1997). Enterococci are recommended for assessing coastal water quality (Ahmed et al. 2009; Abdelzaher et al. 2010).

\section{Conclusions}

The distinct increase in bacterial indicators as the Buffalo River flowed from its source downstream through settlements reveals the deterioration of the water quality and reflects the degradating impact of settlements and anthropogenic activities on the quality of the river. Our results indicate that the bacteriological water quality of the Buffalo River and dams are poor. The use of these source waters for fresh produce irrigation, fullcontact recreation, domestic and herd watering purposes therefore represent significant public health hazards. Future research should focus on the assessment of these surface waters for the presence of bacterial and viral pathogens in the interest of public health. Provision of adequate sanitary infrastructure will help prevent source water contamination, and public health education aimed at improving personal, household and community hygiene is imperative. 
Acknowledgements The authors are grateful to the Water Research Commission (WRC) of South Africa for funding this research and the Education Trust Fund of Nigeria for study bursary for VNC.

Open Access This article is distributed under the terms of the Creative Commons Attribution License which permits any use, distribution, and reproduction in any medium, provided the original author(s) and the source are credited.

\section{References}

Abdelzaher AM, Wright ME, Ortega C, Solo-Gabriele HM, Miller G, Elmir S, Newman X, Bonilla JA, Bonilla TD et al (2010) Presence of pathogens and indicator microbes at a non-point source subtropical recreational marine beach. Appl Environ Microbiol 76:724-732

Ahmed W, Goonetilleke A, Powell D, Chauhan K, Gardner T (2009) Comparison of molecular markers to detect fresh sewage in environmental waters. Water Res 43:4908-4917

American Public Health Association (APHA) (1998) Standard methods for the examination of water and wastewater. 20thEdn. American Public Health Association, American Water Works Association, Water Environment Federation: Washington DC, USA

Anderson KL, Whitlock JE, Harwood VJ (2005) Persistence and differential survival of fecal indicator bacteria in subtropical waters and sediments. Appl Environ Microbiol 71:3041-3048

Ash RJ, Mauck B, Morgan M (2002) Antibiotic resistance of gramnegative bacteria in rivers, United States. Emerg Infect Dis 8:713-716

Bernier J-LT, Maheux AF, Boissinot M, Picard FJ, Bissonnette L, Martin D, Dewailly E, Bergeron MG (2009) Onsite microbiological quality monitoring of raw source water in Cree community of Mistissini. Water Quality Research Journal of Canada 44:345-354

Beuchat LR (2002) Ecological factors influencing survival and growth of human pathogens on raw fruits and vegetables. Microbes and Infection 4:413-423

Bielaszewska M, Mellmann A, Zhang W, Kock R, Fruth A, Bauwens A, Peters G, Karch H (2011) Characterisation of the Escherichia coli strain associated with an outbreak of haemolytic uraemic syndrome in Germany, 2011: a microbiological study. Lancet Infect Dis 11:671-76

Blumenthal UJ, Mara DD, Peasey A, Ruiz-Palacios G, Stott R (2000) Guidelines for the microbiological quality of treated wastewater used in agriculture: recommendations for revising WHO guidelines. Bulletin of the World Health Organization 78:1104-1116

Bosch A, Guix S, Sano D, Pinto RM (2008) New tools for the study and direct surveillance of viral pathogens in water. Current Opinions in Biotechnology 19:1-7

Casadio A, Maglionico M, Bolognesi A, Artina S (2010) Toxicity and pollutant impact analysis in an urban river due to combined sewer overflows loads. Water Sci Technol 61:207-215

Chigor VN, Umoh VJ, Okuofu CA, Ameh JB, Igbinosa EO, Okoh AI (2012) Water quality assessment: surface water sources used for drinking and irrigation in Zaria, Nigeria are a public health hazard. Environ Monit Assess 184:3389-3400

Chigor VN, Umoh VJ, Smith SI (2010a) Occurrence of Escherichia coli $\mathrm{O} 157$ in a river used for fresh produce irrigation in Nigeria. Afr J Biotechnol 9:178-182

Chigor VN, Umoh VJ, Smith SI, Igbinosa EO, Okoh AI (2010b) Multidrug resistance and plasmid patterns of Escherichia coli O157 and other E. coli isolated from diarrhoeal stools and surface waters from some selected sources in Zaria, Nigeria. International Journal of Environmental Research and Public Health 7:3831-3841

Clarke CL, Shackleton SE, Powell M (2012) Climate change perceptions, drought responses and views on carbon farming amongst commercial livestock and game farmers in the semiarid Great Fish
River Valley, Eastern Cape province, South Africa. African Journal of Range \& Forage Science 29:13-23

Davies CM, Long JA, Donald M, Ashbolt NJ (1995) Survival of fecal microorganisms in marine and freshwater sediments. Appl Environ Microbiol 61:1888-1896

Deering AJ, Mauer LJ, Pruitt RE (2012) Internalization of E. coli O157:H7 and Salmonella spp. in plants: A review. Food Res Int 45:567-575

Department of Water Affairs (DWAF) (2010) Strategic Plan 2010/112012. DWAF, Pretoria, South Africa. http://www.dwaf.gov.za/ documents/Other/Strategic\%20Plan/StrategicPlan2010-2013.pdf

Department of Water Affairs (DWAF) (2012) 2012 Green Drop Progress Report. Department of Water Affairs; Pretoria, Republic of South Africa

Department of Water Affairs and Forestry (DWAF) (1996a) South African water quality guidelines (2nd Edn.). Vol. 1: Domestic Use. Pretoria: Department of Water Affairs and Forestry

Department of water affairs and forestry (DWAF) (1996b) South African water quality guidelines (2nd Edn.). Vol. 2: Recreational Use. Pretoria: Department of Water Affairs and Forestry

Department of water affairs and forestry (DWAF) (1996c) South African water quality guidelines (2nd Edn.). Vol. 4: Agricultural Use: Irrigation. Pretoria: Department of Water Affairs and Forestry

Department of Water Affairs and Forestry (DWAF) (1996d) South African water quality guidelines (2nd Edn.). Vol. 5: Agricultural Use: Livestock Watering. Pretoria: Department of Water Affairs and Forestry

Department of Water Affairs and Forestry (DWAF) (1996e) South African water quality guidelines (1st Edn.). Vol. 8: Field Guide Pretoria: Department of Water Affairs and Forestry

Department of Water Affairs and Forestry (DWAF) (2004) Annual Report 2002/2003. DWAF, Pretoria, South Africa

Diergaardt SM, Venter SN, Spreeth A, Theron J, Brozel VS (2004) The occurrence of campylobacters in water sources in South Africa. Water Res 38:2589-2595

Drayna P, McLellan SL, Simpson P, Li S-H, Gorelick MH (2010) Association between rainfall and pediatric emergency department visits for acute gastrointestinal illness. Environ Heal Perspect 118:1439-1443

Effler P, Isaacson M, Arntzen L, Heenan R, Canter P, Barrett T, Lee L, Mamba C, Levine W, Zaidi A, Griffin PM (2001) Factors contributing to the emergence of Escherichia coli $\mathrm{O} 157: \mathrm{H} 7$ in Africa. Emerg Infect Dis 7:812-819

Fong TT, Lipp EK (2005) Enteric viruses of human and animals in aquatic environments: heath risks, detection and potential water quality assessment tools. Appl Environ Microbiol 69:357-371

Gemmell ME, Schmidt S (2012) Microbiological assessment of river water used for the irrigation of fresh produce in a sub-urban community in Sobantu, South Africa. Food Res Int 47:300-305

Gersberg RM, Rose MA, Robles-Sikisaka R, Dhar AK (2006) Quantitative detection of hepatitis A virus and enteroviruses near the United States-Mexico border and correlation with levels of fecal indicator bacteria. Appl Environ Microbiol 72:7438-7444

Gourmelon M, Caprais MP, Segura R, Le Mennec C, Lozach S, Piriou JY, Rince A (2007) Evaluation of two libraryindependent microbial source tracking methods to identify sources of fecal contamination in French estuaries. Appl Environ Microbiol 73:4857-4866

Harwood VJ, Levine AD, Scott TM, Chivukula V, Lukasik J, Farrah SR, Rose JB (2005) Validity of the indicator organism paradigm for pathogen reduction in reclaimed water and public health protection. Appl Environ Microbiol 71:6.3163-3170

He JW, Jiang S (2005) Quantification of enterococci and human adenoviruses in environmental samples by real-time PCR. Appl Environ Microbiol 71:2250-2255 
Hitzfeld, B.C., Hoger, S.J. and Dietrich, D.R (2000). Cyanobacterial toxins: removal during drinking water treatment and risk assessment. Environmental Health Perspectives 108, 113S1-122S1

Hunter PR (2003) Climate change and waterborne and vector-borne disease. J Appl Microbiol 94:37S-46S

Igbinosa EO, Okoh AI (2009) Impact of discharge wastewater effluents on the physico-chemical qualities of a receiving watershed in a typical rural community. Int J Environ Sci Technol 6:175-182

Jagals P (1997) Stormwater runoff from typical developed and developing South African urban developments: Definitely not for swimming. Water Sci Technol 35:133-140

Jurzik L, Hamzaa IA, Puchertb W, Überlac K, Wilhelma M (2010) Chemical and microbiological parameters as possible indicators for human enteric viruses in surface water. Int J Hyg Environ Health 213:210-216

Kistemann T, Claßen T, Koch C, Dagendorf F, Fischeder R, Gebel J, Vacata V, Exner M (2002) Microbial load of drinking water reservoir tributaries during extreme rainfall and runoff. Appl Environ Microbiol 68:2188-2187

Lata P, Ram S, Agrawal M, Shanker R (2009) Enterococci in river Ganga surface waters: propensity of species distribution, dissemination of antimicrobial-resistance and virulence-markers among species along landscape. BMC Microbiol 9:140

LeJeune JT, Besser TE, Rice DH, Berg JL, Stilborn RP, Hancock DD (2004) Longitudinal study of fecal shedding of Escherichia coli O157:H7 in feedlot cattle: predominance and persistence of specific clonal types despite massive cattle population turnover. Applied And Environmental Microbiology 70:377-384

MacIntyre UE, de Villiers FPR (2010) The economic burden of diarrheal disease in a tertiary level hospital, Gauteng, South Africa. J Infect Dis 202:S116-S125

Mills-Robertson F, Crupper SS, Addy ME, Mensah P (2003) Antibiotic resistance and genotyping of clinical group B Salmonella isolated in Accra, Ghana. J Appl Microbiol 94:289-294

Mohanty JC, Ford TE, Harrington JJ, Laksmipathy V (2002) A crosssectional study of enteric disease risks associated with water quality and sanitation in Hyderabad City. J Water Supply Res Technol 51:239-251

Morrison G, Fatoki OS, Persson L, Ekberg A (2001) Assessment of the impact of point source pollution from the Keiskammahoek sewage treatment plant on the Keiskamma River - $\mathrm{pH}$, electrical conductivity, oxygen- demanding substance (COD) and nutrients. Water SA 27:475-480

Muller EE, Ehlers MM, Grabow WOK (2001) The occurrence of $E$. coli $\mathrm{O} 157$ in South African water sources intended for direct and indirect human consumption. Water Res 35:085-3088

Municipal Demarcation Board (MDB) (2010). Municipal demarcation board statistics. http://www.demarcation.org.za Retrieved 13/07/ 2010

Obi CL, Green E, Bessong PO, Villiers B, Hoosen AA, Igumbor EO, Potgieter N (2004) Gene encoding virulence markers among Escherichia coli isolates from diarrhoeic stool samples and river sources in rural Venda communities of South Africa. Water SA 30:37-42

Obi CL, Onabolu B, Momba MNB, Igumbor JO, Ramalivahna J, van Rensburg EJ, Lukoto M, Bessong PO, Green E, Mulaudzi TB (2006) The interesting cross-paths of HIV/AIDS and water in Southern Africa with special reference to South Africa. Water SA 32:323-344

Obi CL, Potgieter N, Bessong PO, Matsaung G (2002) Assessment of the microbial quality of river water sources in rural Venda communities in South Africa. Water SA 28:287-292

Odjadjare EEO, Okoh AI (2010) Prevalence and distribution of Listeria pathogens in the final effluents of a rural wastewater treatment facility in the Eastern Cape Province of South Africa. World J Microbiol Biotechnol 26:297-307

Odjadjare EEO, Obi LC, Okoh AI (2010) Municipal wastewater effluents as a source of listerial pathogens in the aquatic milieu of the
Eastern Cape Province of South Africa: a concern of public health importance. International Journal of Environmental Research and Public Health 7:2376-2394

Okoh AI, Odjadjare EE, Igbinosa EO, Osode AN (2007) Wastewater treatment plants as a source of microbial pathogens in the receiving watershed. Africa Journal of Biotechnology 6:2932-2944

Payment, P. and Riley, S.M. (2002) Resolving the global burden of gastrointestinal illness: A call to action. American Academy of Microbiology. Washington DC, United States of America 1-25.

Pruss A, Kay D, Fewtrell L, Bartram J (2002) Estimating the burden of disease from water sanitation and hygiene at a global level. Environ Heal Perspect 110:537-542

River Health Programme (2004) State-of-Rivers Report: Buffalo River System. Department of Water Affairs and Forestry, Pretoria, South Africa, 1-41

Schets FM, van Wijnen JH, Schijven JF, Schoon H, de Roda Husman AM (2008) Monitoring of waterborne pathogens in surface waters in Amsterdam, The Netherlands, and the potential health risk associated with exposure to Cryptosporidium and Giardia in these waters. Appl Environ Microbiol 74:2069-2078

Shuval, H I (1990) Wastewater irrigation in developing countries: health effects and technical solutions. Summary of World Bank Technical Paper No. 51. The World Bank, Washington DC, United States of America, 1-19.

Sinton LW, Hall CH, Lynch PA, Davies-Colley RJ (2002) Sunlight inactivation of fecal indicator bacteria and bacteriophages from waste stabilization pond effluent in fresh and saline waters. Appl Environ Microbiol 68:1122-1131

Solomon EB, Yaron S, Mathews KR (2002) Transmission of Escherichia coli 0157: H7 from contaminated manure and irrigation water to lettuce plant tissue and its subsequent internalization. Appl Environ Microbiol 68:397-400

Stewart-Tull DES (2001) Vaba, hariza, kholera, foklume or cholera: in any language, still the disease of seven pandemics. J Appl Microbiol 91:580-581

Tebbut THY (1992) Principles of water quality. Pergamon, Oxford, England, pp 1-251

Toranzos GA, McFeters GA (1997) Detection of indicator microorganisms in environmental fresh waters. In: Hurst CJ, Knudsen GR, McInerney MJ, Stetzenbach LD, Walter MV (eds) Manual of environmental microbiology. American Society for Microbiology, Washington, D.C., pp 184-194

United States Environmental Protection Agency (USEPA) (1986) Ambient water quality criteria for bacteria. EPA440/5-84-002, U.S. Environmental Protection Agency Office of Water. Washington, DC

United States Environmental Protection Agency (USEPA) (1992) Guidelines for water reuse. EPA/625/R-92/004, U.S Environmental Protection Agency Office of Wastewater Enforcement and Compliance. Washington, DC

United States Environmental Protection Agency (USEPA) (2004) Comprehensive surface water treatment rules quick reference guide: unfiltered systems. EPA 816-F-04-001, U.S. Environmental Protection Agency Office of Water. Washington, DC

United States environmental protection agency (USEPA) (2010) Sampling and consideration of variability (temporal and spatial) for monitoring of recreational waters. EPA-823-R-10-005 U.S. Environmental Protection Agency Office of Water, Washington, DC

Whitman RL, Nevers MB (2004) Escherichia coli sampling reliability at a frequently closed Chicago beach: monitoring and management implications. Environ Sci Technol 38:4241-4246

Wilczynski JA, Peters S, House J, Hill V, Schneeberger C, Xiao L, Dearen T, Webeck J (2012) Outbreak of cryptosporidiosis associated with a firefighting response - Indiana and Michigan, June 2011. MMWR Morb Mortal Wkly Rep 61:153-156 
Williams AP, Quilliam RS, Thorn CE, Cooper D, Reynolds B, Jones DL (2012) Influence of land use and nutrient flux on metabolic activity of E. coli $\mathrm{O} 157$ in river water. Water Air Soil Pollut 223:3077-3083

World Health Organization (2008) Guidelines to drinking water quality (3rd Edn). Vol. 1 World Health Organization. Geneva, Switzerland pp.1-666
Zahid MSH, Udden SMN, Faruque ASG, Calderwood SB, Mekalanos JJ, Faruque SM (2008) Effect of phage on the infectivity of Vibrio cholerae and emergence of genetic variants. Infect Immun 76:5266-5273

Zhang XX, Zhang T, Fang HHP (2009) Antibiotic resistance genes in water environment. Appl Microbiol Biotechnol $82: 397-414$ 